\title{
Assessment of Seasonal Changes in the Water chemistry of Valapattanam and Munderikadavu River in Kerala, Tamilnadu, India
}

\author{
*Saranya. $\mathrm{M}^{1}$ and Dhanalakshmi. $\mathrm{B}^{2}$ \\ ${ }^{1}$ Post graduate student, Department of Zoology, Nirmala College for women, Coimbatore-18. \\ ${ }^{2}$ Assistant Professor, Department of Zoology, Nirmala College for women, Coimbatore-18. \\ *Corresponding Author: Saranya.M
}

\begin{abstract}
In the present study an attempt has been made on assess the hydrological characteristics of Valapattanam river, Munderikadavu River located in Kannur district of Kerala. The study was carried out for a period of six months i.e. for two seasons from July 2016 to Dec 2016. Monthly samples have been collected, analysed and the mean values were represented seasonally. Important hydrological parameters like Water temperature, Odour, pH, Turbidity Dissolved oxygen, Dissolved carbon-di-oxide were taken and analysed in the present study along with heavy metals like Zinc, Copper, Cobalt, Manganese, Chromium, Lead, Cadmium, Nickel, Selenium and Mercury. The results of the present study indicated that the hydrological parameters of the rivers where noted to be maximum during premonsoon in upper stream of rivers (Stn.1) and minimum during postmonsoon season in the downstream of rivers (Stn.2). The results of the present study indicates that the current status of decline in water quality and degradation of river habitat is due to continuous influx of more domestic and industrial discharge into the river which may cause gradual lead to eutrophication.
\end{abstract}

Key words: River water, Hydrological parameters, Effluents, Heavy metals, Eutrophication

Date of Submission: 03-07-2017

Date of acceptance: $22-07-2017$

\section{Introduction}

Water pollution is as old as man himself is a serious environmental problem in the world according to current scenario. The aquatic water bodies are degraded mainly due to the discharge of organic and inorganic chemicals via anthropogenic activities. As a result, water the most vital source for all kinds of life on planet earth and its sources are becoming unhealthy, adversely getting affected because of undesirable changes brought by all kinds of human activities both qualitatively and quantitatively on the hydrochemistry (i.e. Physicochemical) and biochemical conditions (Nutrients) causing sudden and large scale mortality of fish population and human health. Some effluents with major heavy metal as components are directly discharged from small and large scale industrial, municipal sewage and come from polluted runoff in urban and agricultural areas too. These Xenobiotics are the main pollutants of the water bodies because they are very harmful as a result of their non-biodegradable nature, long biological half-life and their potential to accumulate in different body parts of organism especially fish which lives in water as their habitat. They can also be concentrated along the food chain, producing their toxic effect at points after far removed from the source of pollution. Thus compared to other types of aquatic pollution, heavy metals pollution is less visible but its effects on the ecosystem and humans can be intensive and very extensive (Edem et al., 2008).Several workers like Barik and patel, 2004, Singh et al., 2005, Sachidanandamurthy and Yajurvedi, 2006,Muhamed Ashraf and Mukundan, 2007, Najafpour, 2008, Priyanka Trivedi, 2009, Nikhil Raj and Azeez 2009, Singkran, 2010, Yadav and Kumar, 2011 and many others have conducted studies related to water quality in India rivers. In view of the above description of the current status of Indian rivers, the present investigation was carried out to assess the water quality in selected stations of Kerala rivers to create awareness among the habitants who use the river water for domestic purpose, irrigation and also consume fish caught from these stations which also would have the pollution impact that may bring bad impact on the public health.

\section{Materials and Methods}

Study area: Valapattanam River(Stn.1-Upper stream);Munderikadavu River(Stn.2-Downstream); Kannur district, Kerala (Fig.1), India is a famous river located in the South Indian state of Kerala. Valapattanam River and Munderikdavu River originates Brahmagiri of Western Ghats of Kodagu and discharge to the Arabian Sea.These river are the main source of water for farming, fishing and for domestic use. Many agricultural lands 
and industries are located near the river. The effluents from industries and pesticides are polluted the river water. Many years ago these river were used as mean of transportation(Fig.2).

Study stations: Stn.1 sampling point is located around the many timber industrial, agricultural and irrigation activities taking place. This sample point may help to evaluate the sediment load, soil erosion and agricultural activities that deteriorate the water quality. Stn.2 Sampling point is mostly utilized by the rural and urban community in fetching water for drinking, bathing, washing clothes, cattle, drinking etc. The local community extensively utilizes the water for daily activities; such point may help to evaluate the effect of human activities on water quality changes.

Fig.1 showing the linked map of Kerala in India and the study.

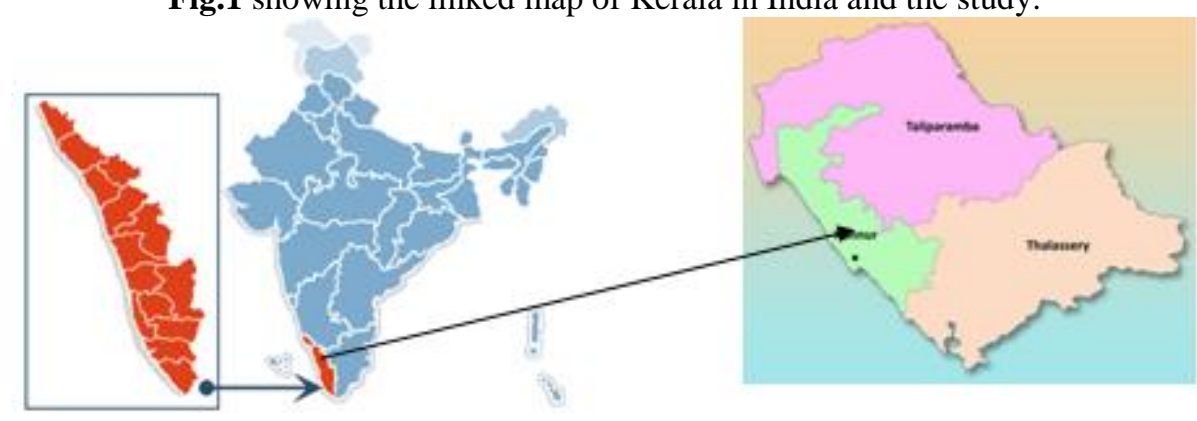

Fig: 2 showing the Google map of the study stations Stn.1 (Valapattanam River) and Stn.2 (Munderikadavu River)

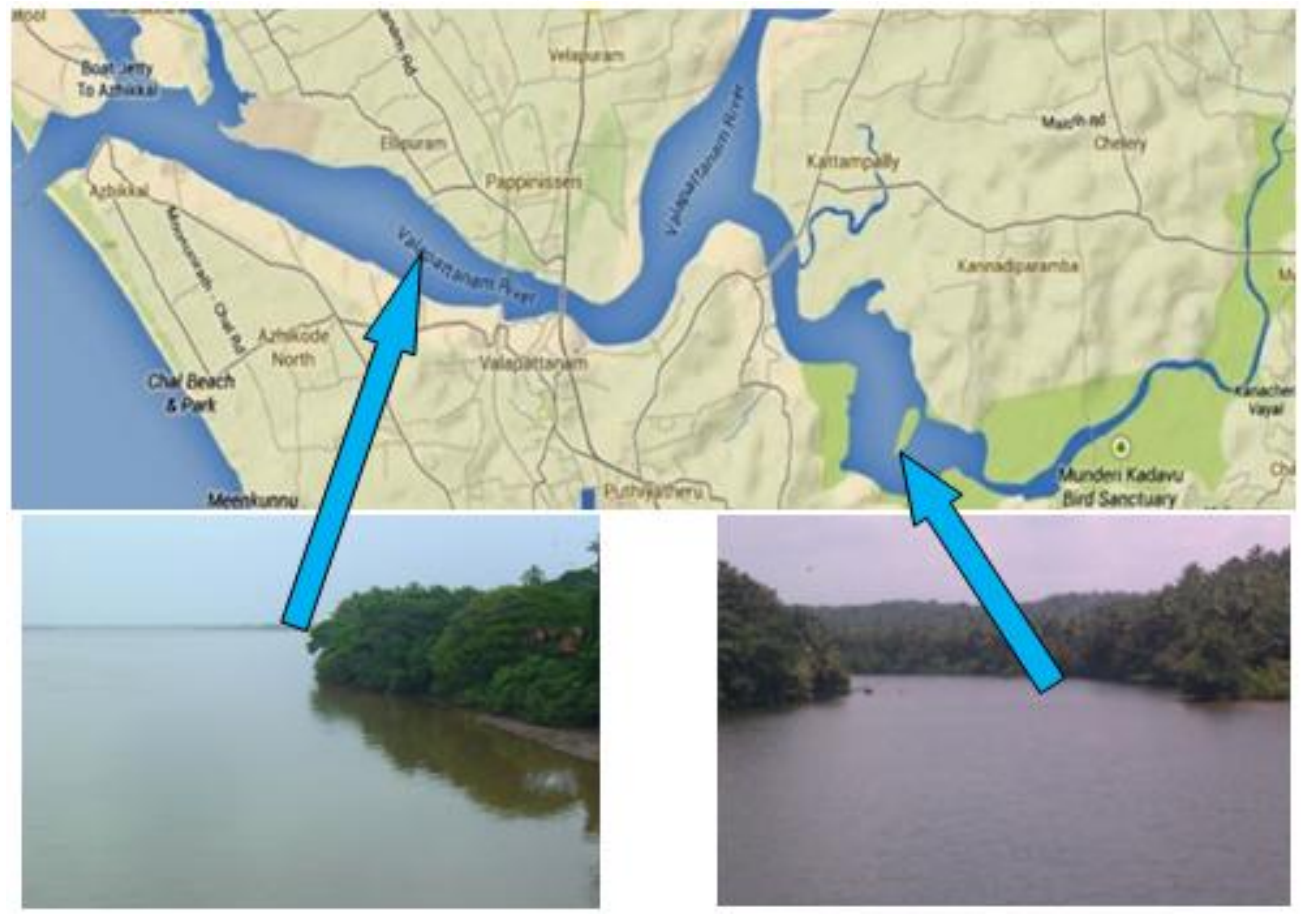

Station.1(Valapattanam River)

Station.2 (Munderikadavu River)

Sampling Selection: Two sampling sites Valapattanam River (Upper stream) and Munderikadavu River (Downstream) were selected to represent the downstream water quality variations.

These two major sampling points were selected based on: i) The rate of human interference ii) And other industrial activities iii) And agricultural activities iv)The nature of place v) The usage of water; on pollution load

These two sampling points were taken in systematic manner by which such points believed to show the relative water quality changes along the River (Fig:2 ).

Water sample collection: Samples were collected in $1000 \mathrm{ml}$ polyethylene plastic bottles from two sampling points by direct immersion of bottles at water sampling points handled by rope. The containers must be capable of being tightly sealed either by stopper or cap. The bottle must be soaked with $10 \% \mathrm{Hcl}$ for $24 \mathrm{hrs}$ and then 
thoroughly cleaned and rinsed with distilled water. Before collection bottles were washed with concentrated nitric acid and distilled water to avoid contamination for estimation of heavy metals. Bottles were preserved using icebox and transported to the laboratory of within 6-9hrs immediately after sample collection for physicochemical analysis and heavy metal analysis. Water sampling and preservation techniques followed were the standard methods of (APHA,2012).

Analysis of physicochemical parameters: The water samples were analysed for the physicochemical parameters: Physical parameters: Temperature (Standard Centrifuge Thermometer), colour (Visual), odour (Smell); Chemical parameters: $\mathrm{pH}$ (pH meter-), Dissolved oxygen (Wrinkler's Method, 1972), Dissolved carbon-di-oxide (Titration method); Heavy metal analysis: Zinc, Copper, Cobalt, Manganese, Chromium, Lead, Cadmium, Nickel, Selenium, Mercury were analysed using A-0303-0152 atomic absorption spectrophotometer.

Data Analysis:All the data provide in the tables were the average of three replicates.

\section{Results and Discussion}

The entire fabric of life is woven around water so it has a unique place on planet as supporting factor of life on earth. Ignorant, irresponsible, and careless management has brought the waters of the world to pathetic situation, with severe water shortage at present in different parts of the world. This important resource for life has currently been polluted to a point of crisis because of industrial development and unplanned urbanization. As water quality provides current information about the concentration of various solutes at given place and time, understanding the water quality is vital for appropriate management of the earth's aquatic ecosystem. Thus hydrological parameters such as colour, smell, temperature, $\mathrm{pH}$, turbidity, dissolved oxygen and dissolved carbon dioxide etc. are very important form drinking, irrigation, fish production quality point of view along with recreation and other purposes. The water quality presently getting deteriorated in river water is usually as a results from acidification, heavy metal contamination, organic pollution, obnoxious fishing practices and excessive nutrient finally leading to eutrophication.

So in the present study the physicochemical properties of water quality of selected stations (Stn.1 and Stn.2) were assessed to give a proper indication of the status, productivity and sustainability of a water body to provide valuable information on the quality of the water, the source (s) of the variations and their impacts on the functions and biodiversity of the rivers. Looking at the importance of understanding physicochemical properties of water in a water body for supporting various biota, a study was planned to find out physicochemical status of the river waters of Kerala at two different sites (Stn.1: Valapattanam and Stn.2: Munderikadavu) during two different seasons (Pre-monsoon \& Post-monsoon season) and represented in Table-1.

Colour: The colour indicate water quality. The colour change of water is due to contamination of organic and inorganic substances. In Pre-monsoon both river water (Valapattanam and Munderikadavu) was observed muddy colour due to less outflow and more influx of runoff from adjacent areas and maximum incoming of industrial effluents. During Post monsoon the river water colour was observed to be slightly transparent at both selected sites due to heavy rain pour and dilution of water column.

Odour: During the Pre-monsoon season at Stn.1 water sample observed to have foul and fishy smell and at Stn.2 water samples were observed to be foul and fishy smell. In post monsoon season water sample of Stn.1 was observed to have detergent smell and at Stn.2 it was observed to be algal and fishy smell. The odour of the water is indicating the pollution of the river by many human purposes (bathing, washing and fishing).

Temperature: Temperature is a measure of the intensity of heat stored in a volume of water measured in calories $\left({ }^{\circ} \mathrm{C}\right)$ was basically important for its effects on certain chemical and biological reactions taking place in biological organisms. During the present study in pre monsoon water temperature at Stn.1 was noted to be $27^{\circ} \mathrm{C}$ while in Stn. 2 water temperature was record as $26^{\circ} \mathrm{C}$. During post monsoon season Stn. 1 water temperature was $24^{\circ} \mathrm{C}$ and $\mathrm{Stn} .2$ was $23^{\circ} \mathrm{C}$. Water temperature regulates various abiotic characteristics and activities of an aquatic ecosystem so it is of enormous significance so during the present study season pre-monsoon at Stn. 1 the temperature was noted to be maximum due to direct mixing of industrial effluents and at Stn.2 due less influx of fresh waters and mixing of urban runoff the temperature was noted high and during post-monsoon the temperature was noted to be moderate due to heavy inflow of freshwater from surrounding due to rain and dilution of water. Decreased value of temperature during post-monsoon seasons are due to low ambient temperature (Gyananath etal., 2000)

pH: Hydrogen ions (acidic) as well as hydroxyl ions (alkaline) are the result of the ionization of water. Any change in the concentration of any one of these ions brings about a change in the concentration of the other. The $\mathrm{pH}$ changes in water are governed by the amount of free $\mathrm{CO}_{2}$, Carbonates and Bicarbonate. These changes are accompanied by the changes in other physicochemical aspects that in turn influence quality of water. So it is important physiochemical parameter of water. In Pre-monsoon season $\mathrm{pH}$ of water ranged from 5.0 to 6.0 at Stn.1 and Stn.2. During Post-monsoon season pH of the water ranged from 6.0 to7.0. During Pre-monsoon at Stn.1 and Stn.2 the pH was noted to be acidic which is due to mixing of pollutants from small and large scale 
industries and timber factories situated on the bank of river and also due to less flow of water while at Stn.1 during Post-monsoon it was noted to be slightly acidic and at Stn.2 it was observed to be neutral which mean less inflow of effluent and pollutants from adjacent areas and increase in water level due to rain. The present findings are supported by Esmaeili and Johal, 2005; Negi etal., 2006.

Dissolved Oxygen: The dynamics of oxygen distribution in inland waters is essential to the respiratory metabolism of most aquatic organisms. It is governed by a balance between inputs from the atmosphere and photosynthesis and losses from the chemical and biotic oxidations. It is a very important parameter for the survival of fishes and other aquatic organisms and also needed for many chemical reactions that are important for fresh water body functioning. Dissolved Oxygen is regulator of metabolic activities of organisms and thus governs metabolism of the biological community as a whole and also act as an indicator of trophic status of the water body (Saksena and Kaushik, 1994). In Pre-monsoon the dissolved oxygen values recorded was $4.13 \mathrm{mg} / \mathrm{l}$ and4.24 mg/l at Stn.1 and Stn.2. During Post-monsoon season while 4.33mg/l and 4.53mg/l Stn.1 and Stn.2. During the study period at Stn.1 and Stn.2 during Post-monsoon season maximum dissolved oxygen was recorded which may be due to dilution of river water, rise in water column, less inflow of urban runoff and effluents from adjacent areas while Pre-monsoon the dissolved oxygen amount recorded were noted to be minimum due to incoming of more waste and pollutant from adjacent factories and industries which are located on the left and right sides of river banks.

Dissolved Carbon-di-oxide: Two major processes photosynthesis and respiration influence the amount of carbon-di-oxide in water. Free carbon-di-oxide which accumulates in water is due to microbial activity and respiration of organisms which imparts the acidity to the water because of the formation of carbonic acid. Hence, carbon-di-oxide forms an important component in aquatic ecosystem. The amount of dissolved carbondi-oxide level at Stn.1 in Pre- monsoon season was $6.68 \mathrm{mg} / \mathrm{land} 6.52 \mathrm{mg} / \mathrm{l}$ at $\mathrm{Stn} .2$. The maximum free carbondi-oxide in Pre-monsoon may be attributed to higher rate of decomposition of organic matter due to comparatively higher temperature. During Post-monsoon season dissolved carbon-di-oxide were recorded to be $5.99 \mathrm{mg} / \mathrm{l}$ and $5.66 \mathrm{mg} / \mathrm{l} \mathrm{Stn.1}$ and Stn.2. Fluctuation in the carbon-di-oxide was noted among the stations and seasons. The organic decomposition, respiration, photosynthesis, diffusion and runoffs could also account for the fluctuation seen in the carbon-di-oxide levels during Post-monsoon season.

Table: 1 showing seasonal variations in the physicochemical parameters of water samples collected from Stn.1 and Stn.2.

\begin{tabular}{|l|c|c|c|c|}
\hline \multirow{2}{*}{$\begin{array}{c}\text { Hydrological } \\
\text { Parameter }\end{array}$} & \multicolumn{2}{|c|}{ Pre-monsoon season } & \multicolumn{2}{c|}{ Post-monsoon season } \\
\cline { 2 - 5 } & $\begin{array}{c}\text { Upper stream } \\
\text { (Stn.1) }\end{array}$ & $\begin{array}{c}\text { Down Stream } \\
\text { (Stn.2) }\end{array}$ & $\begin{array}{c}\text { Upper stream } \\
\text { (Stn.1) }\end{array}$ & $\begin{array}{c}\text { Down Stream } \\
\text { (Stn.2) }\end{array}$ \\
\hline Temperature $\left({ }^{\circ} \mathrm{C}\right)$ & 27 & 26 & 24 & 23 \\
\hline odour & Foul & Fishy & Detergent & Algal \&fishy \\
\hline Colour & Muddy & Muddy & Transparent & 6 \\
\hline $\mathrm{pH}$ & 5 & 6 & 47 & 20 \\
\hline Turbidity $((\mathrm{mg} / \mathrm{l})$ & 52 & 37 & 4.33 & \\
\hline Dissolved oxygen $(\mathrm{mg} / \mathrm{l})$ & 4.13 & 4.24 & 5.99 & 4.53 \\
\hline Dissolved carbon-di-oxide $(\mathrm{mg} / \mathrm{l})$ & 6.68 & 6.52 & & 5.66 \\
\hline
\end{tabular}

Metal concentration in water: The mean concentration result of heavy metal in water column at Valapattanam (Stn.1) and Munderikadavu(Stn.2).In this present study ten heavy metals such as zinc, copper, cobalt, lead, nickel, cadmium, selenium, chromium, manganese and mercury in the two sites of river (Valapattanam River and Munderikadavu River) were analysed for two seasons (Pre-monsoon and Post-monsoon).In the study Stn.1 (Valapattanam) heavy metal value recorded during Pre-monsoon season were Zinc- $0.32 \mu \mathrm{g} / \mathrm{L}, \mathrm{Copper}-2.9 \mu \mathrm{g} / \mathrm{L}$,

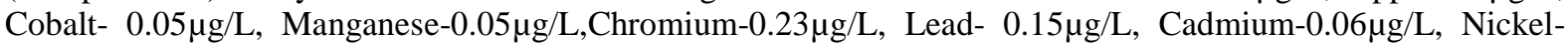
$0.08 \mu \mathrm{g} / \mathrm{L}$, Selenium- $0.06 \mu \mathrm{g} / \mathrm{L}$, and Mercury-0.003 $\mu \mathrm{g} / 1$. At Stn.2 (Munderikadavu) the recorded heavy metal

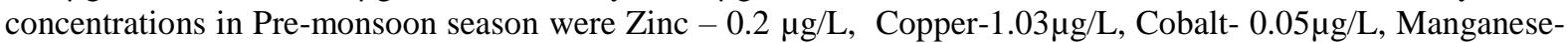
$0.06 \mu \mathrm{g} / \mathrm{L}$, Chromium-0.24 $\mu \mathrm{g} / \mathrm{L}$, Lead-0.002 $\mu \mathrm{g} / \mathrm{L}$, Cadmium-0.05 $\mu \mathrm{g} / \mathrm{L}$, Nickel-0.06 $\mu \mathrm{g} / \mathrm{L}$, Selenium-0.06 $\mu \mathrm{g} / \mathrm{L}$ andMercury- $0.005 \mu \mathrm{g} / \mathrm{L}$. The result of heavy metals analysis in water states that the water in Pre-monsoon season at Stn.1 water was highly polluted when compare with Stn. 2 because timber industries and agricultural fields are located near the Stn.1. The main sources of pollution of the river at Stn.2 were urban, agricultural, and domestic wastewaters. In addition, the major sources of pollution in agricultural wastewater are fertilizers containing heavy metals such as $\mathrm{Cd}, \mathrm{Pb}, \mathrm{Cr}, \mathrm{Zn}$, and $\mathrm{Ni}$. Heavy metal concentration indicates of Stn. 1 is polluted compared to Stn.2.

In Post-monsoon the value of heavy metal recorded at Stn.1 water sample are noted to be Zinc -0.26

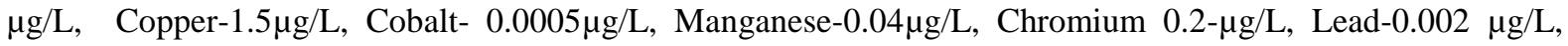
Cadmium-0.05 $\mu \mathrm{g} / \mathrm{L}$, Nickel-0.06 $\mu \mathrm{g} / \mathrm{L}$, Selenium-0.06 $\mu \mathrm{g} / \mathrm{L}$, Mercury0.005 $\mu \mathrm{g} / \mathrm{L}$ and Stn.2 water metal concentrations were noted to be Zinc $-0.12 \mu \mathrm{g} / \mathrm{L}$, Copper- $0.014 \mu \mathrm{g} / \mathrm{L}$, Cobalt- $0.023 \mu \mathrm{g} / \mathrm{L}$, Manganese- 


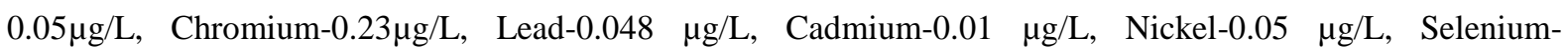
$0.021 \mu \mathrm{g} / \mathrm{L}$, Mercury- $0.002 \mu \mathrm{g} / \mathrm{L}$. From the results it clearly shows that Stn. 1 is highly polluted in Post-monsoon season also as it receives huge amount of industrial effluents from timber and craft industry and agricultural land runoff like pesticides and mixing of residential wastes.

Table: 2 showing seasonal variations of heavy metals of water samples collected from Stn.1 and Stn.2.

\begin{tabular}{|l|c|c|c|c|}
\hline \multirow{2}{*}{$\begin{array}{c}\text { Hydrological } \\
\text { Parameter }\end{array}$} & \multicolumn{2}{|c|}{ Pre-monsoon season } & \multicolumn{2}{c|}{ Post-monsoon season } \\
\cline { 2 - 5 } & $\begin{array}{c}\text { Upper stream } \\
(\text { Stn.1) }\end{array}$ & $\begin{array}{c}\text { Down Stream } \\
\text { (Stn.2) }\end{array}$ & $\begin{array}{c}\text { Upper stream } \\
\text { (Stn.1) }\end{array}$ & $\begin{array}{c}\text { Down Stream } \\
\text { (Stn.2) }\end{array}$ \\
\hline Zinc $(\mu \mathrm{g} / \mathrm{L})$ & 0.32 & 0.20 & 0.26 & 0.12 \\
\hline Copper $(\mu \mathrm{g} / \mathrm{L})$ & 2.90 & 1.030 & 1.50 & 0.014 \\
\hline Cobalt $(\mu \mathrm{g} / \mathrm{L} /)$ & 0.05 & 0.05 & 0.0005 & 0.023 \\
\hline Manganese $(\mu \mathrm{g} / \mathrm{L})$ & 0.05 & 0.06 & 0.04 & 0.05 \\
\hline Chromium $(\mu \mathrm{g} / \mathrm{L})$ & 0.23 & 0.24 & 0.2 & 0.23 \\
\hline Lead $(\mu \mathrm{g} / \mathrm{L})$ & 0.15 & 0.06 & 0.002 & 0.048 \\
\hline Cadmium $(\mu \mathrm{g} / \mathrm{L})$ & 0.06 & 0.03 & 0.06 & 0.01 \\
\hline Nickel $(\mu \mathrm{g} / \mathrm{L})$ & 0.08 & 0.05 & 0.06 & 0.05 \\
\hline Selenium $(\mu \mathrm{g} / \mathrm{L})$ & 0.06 & 0.01 & 0.005 & 0.021 \\
\hline Mercury $(\mu \mathrm{g} / \mathrm{L})$ & 0.003 & 0.002 & & 0.002 \\
\hline
\end{tabular}

In both seasons copper are highly present in both station collected waters. This relatively high copper may be attributable to wastes in flood water run- off, leachates from garbage dumps and other forms of domestic wastes washed into the river by the inhabitant. However, the mean concentration value was lower than the WHO recommended standard $(1.0 \mathrm{mg} / \mathrm{l})$ for portable drinking water. Copper pollution is through extensive use of fungicides, algaecides, mollucides, insecticides and discharge of wastes. (Mohammed Authmanet al., 2015).In aquatic ecosystem, dissolved Nickel concentrations are generally between 0.005 and $0.01 \mathrm{mg} \mathrm{1-1} \mathrm{(Galvin,} \mathrm{1996).} \mathrm{Higher} \mathrm{concentration} \mathrm{of} \mathrm{nickel} \mathrm{in} \mathrm{the} \mathrm{present} \mathrm{may} \mathrm{be} \mathrm{attributed} \mathrm{to} \mathrm{leachates} \mathrm{from}$ fertilizers applied on the rubber plantation and other domestic activities that are carried out in the river by the inhabitants. The nickel content in all samples were higher than the permissible limit $0.02 \mathrm{mg} / \mathrm{l}$ defined by WHO, (2003). Cr was noted to be higher than the value $(0.05 \mathrm{mg} / \mathrm{l})$ recommended for portable drinking water by WHO (1984). Several workers Sponza and Karaoglue, 2002; Rewat et al., 2003; Sing and Mosley, 2003 previous scientific report states that during this study seasons Pre-monsoon and Post-monsoon, in these study area many health problems are have been reported. Nickel toxicity is generally low (Khangarot and Ray, 1990) but elevated concentration can cause sub lethal effects.

Cadmium (Cd) metal has a high profile inhuman toxicology where it has been transferred at high concentration through food chain. In water, the main point source is effluents from electroplating works. Cd is strongly adsorbed as organic and inorganic particles in water. Although it can form soluble complex with humic substance, but the toxicity is not reduced like that in case of $\mathrm{Cu}$ (Rashed, 2001). Cadmium level was highly present in both water samples (Stn.1 and Stn.2) when compared with permissible limit 0.005mg/l. Zinc (Zn) metal is widely detected in freshwater due to relatively high solubility. $\mathrm{Zn}$ is an essential element for aquatic life. Therefore, small amount of $\mathrm{Zn}$ in the water or in the diet is essential. In general the organisms will have internal mechanisms to transport $\mathrm{Zn}$ around the body in order to manufacture vital enzymes. The data indicated that Zinc content of water was below the permissible limit of $3.0 \mathrm{mg} / \mathrm{l}$ reported by WHO, (2003). Manganese is an essential constituent for bone structure, reproduction and normal functioning of the enzyme system (Fleck, 1976). It is toxic only when present in higher amounts, but at low levels is considered as micro nutrient (Sarkka et al., 1978). Valapattanam river and Munderikadavu river water containing high amount of lead comparing with permissible limit $(0.015 \mathrm{mg} / \mathrm{l})$.

Lead is non-essential element and higher concentrations can occur in aquatic organisms close to anthropogenic sources. It is toxic even at low concentrations and has no known function in biochemical processes. The WHO has proposed that chromium is a human carcinogen. Several studies have been studies have shown that chromium VI compounds can increase the risk of lung cancer. Large amount of chromium present in the both river water comparing with permissible limit $(0.1 \mathrm{mg} / \mathrm{l})$. Mercury is a dangerous heavy metal it release occur by both natural and anthropogenic processes like cement production, consumer product release etc. $0.003-0.005 \mathrm{mg} / \mathrm{l}$ mercury present in the water of Valapattanam river and Munderikadavu river water. Permissible limit of mercury is $0.002 \mathrm{mg} / \mathrm{l}$. Cobalt is an element that occurs naturally in the environment in air, water, soil, rocks, plant,and animal. It may also enter air and water through run off when rain water through soil and rocks to the water. The present data showed that the cobalt content of both samples were lower than the permissible limit of $0.05 \mathrm{mg} / \mathrm{l}$ (WHO, 2003).

Thus from the results on physicochemical parameters and heavy metals analysed in the present study most of the parameters were noted to be above the permissible limit of Indian standards WHO,2010 which means that the river at Valapattanam (Stn.1) and Munderikadavu (Stn.2) was getting gradually polluted day by 
day. On comparing with Valapattanam River (Stn.1) hydrological parameters of Munderikadavu River Stn.2 seems to less polluted. Seasonally it was observed that during premonsoon season these stations (Stn.1 and Stn.2) were noted to be highly polluted than post monsoon season. So care must be taken to preserve these natural freshwater resources form the getting destructed and conserve them for future generation and to sustain their natural habitat and beauty and biodiversity. To ensure for the health and environmental safety of the river stakeholders the limnologist reiterate the need for continued monitoring of the aquatic resource under strict water quality surveillance.

\section{Acknowledgment}

The authors are thankful to the Principal, Head of the Department, Department of Zoology, Nirmala College for women, Coimbatore-18 for providing facilities like Lab and Library for the present study.

\section{References}

[1]. APHA. (2012). Standard Methods for examination of water and wastewater. 22nd ed. Washington: American Public Health Association; $1360 \mathrm{pp}$.

[2]. Barik. R.N. and R.K. Patel. (2004). Seasonal variation of water quality of Atharabanki river near Paradip. Indian Journal of Environmental Protection, 24 (03): 161-166.

[3]. Edem, C. A., Osabor, V., Iniama, G., Etiuma, R. and Eke, J. (2008). Distribution of heavy metals in bones, gills, liver and muscles of (Tilapia) Oreochromis niloticus from Hensha Town Beach market, in Calabar, Nigeria. Pak.J. Nutri,8(8):1209-1211.

[4]. Esmaeili H.R. and Johal M.S. (2005). Study of physicochemical parameters of water of Gobind Sagar reservoir, India. Proc. Nat. Sem. New Trends in Fishery Development in India. (Ed: M.S. Johal), Punjab University, Chandigarh, 173-177.

[5]. Fleck, H. (1976). Introduction to Nutrition, 3rdedn. MacMilanPublishingCo., Inc., NewYork, 552pp.

[6]. Galvin.R.M.1996. occurrence of metals in waters: An overview. Water,S.A., 22:7-18.

[7]. Gyananath, G. Shevnikar S.V. and Samiuddin S.(2000). Water quality analysis of river Godavari during "Holimela" at Nanded, Poll. Res, 19(4): 673

[8]. Khangarot, B.S and P.K. Ray. (1990). Correlation between heavy metal and acute toxicity values in Daphnia magna and fish. Bull. Environ. Contam.Toxicol,38: 722-726.

[9]. Kunwar P. Singh, Dinesh Mohan, Vinod K. Singh, Amrita Malik.(2005). Studies on distribution and fractionation of heavy metals in Gomti river sediments-a tributary of the Ganges, India.Journal of Hydrology,312: 14-27.

[10]. Mohammad Authman, M.N., Mona Zaki, S., Elsayed Khallaf, A., Hossum Abbas. (2015). Use of fish as bio-indicator of the effects of heavy metals pollution. J Aqua Res Development, 6(4):1-13.

[11]. Muhamed Ashraf P. and M. K. Mukundan. (2007).Seasonal Variations in water quality of four stations in the Periyar River Basins.J. Env. Sci. \& Engg, 49(2):127-132.

[12]. Najafpour Sh. (2008). “Evaluation of Spatial and Temporal Variation in River Water Quality” Int. J. Environ. Res. 2(4) $349-358$.

[13]. Nanji, J.C., Uzairu, A., Harrison, M.F and Balarable, M. (2007). Heavy metal in muscles of Orechromis niloticus and Synodantis shall of River Galma, Zaria, Nigeria. Biological and Environmental Sciences Journal for the tropics, 4(1): 181-189.

[14]. Negi R K., Johal M S and Tarana Negi., (2006), Study of the physicochemical parameters of water of Pangdam reservoir, Himachal Pradesh: A. Ramsar site, Him.J.Env.20(2): 247-251.

[15]. Nikhil Raj and P. A. Azeez. (2009). Spatial and Temporal variations in surface water chemistry of a tropical river, the river Bharatapuzha, India. Current Science, 96(2): 245-250.

[16]. Priyanka Trivedi. (2009).Evaluation of Water Quality: Physicochemical Characteristics of Ganga River at Kanpur by using Correlation Study.Nature and Science, 1(6):91-94.

[17]. Rashed MN. (2001). Cadmium and lead levels in fish (Tilapianilotica) tissues as biological indicator for lake waterpollution. Environ Monit Assess. 68(1):75-89.

[18]. Rawat, M., Moturi, MC and Subrahmania, V. (2003). Inventory complication and distribution of heavy metal in waste water from small scale industrial areas of Delhi, India. Journal ofEnvironmental Monitor, 5(6):906-912.

[19]. Sachidanandamurthy, K.L. and H.N. Yajurvedi. (2006). A study on physicochemical parameters of an aquaculture body in Mysore city, Karnataka, India. J. Environ. Biol.27:615-622.

[20]. Saksena, D.N and Kaushik. (1994). Tropic status and habitat ecology of entomofauna of three water bodies at Gwalior, MadhyaPradesh, India. Perspective In Entomological Research. Scientific publishers, Jodhpur.

[21]. Sarkka, J.; Hatulla, M. L.; Paasivirta, J. andJanatiunem, J. (1978). Mercury andchlorinated hydrocarbons in food chain ofLake Paynma, Finland. Holarctic Ecol. 1:326- 332.

[22]. Sing,S and Mosley, L.M. (2003). Trace metal levels in drinking water on Viti Levu, Fiji Islands. S. Pac. J. Nat. Sci. 21:31-34.

[23]. Singkran. N. (2010). Determining water conditions in the North eastern rivers of Thailand using time series and water quality index models, Journal of Sustainable Energy and Environment, 47-58.

[24]. Sponza and Karayoglue. (2002). Environmental geochemistry and pollution studies of Aliga metal industry district. Environment International. 27(7):541-553.

[25]. WHO. (1984). International Standards for drinking water. 3rd guidelines for drinking water quality. Vol. 2: Health criteria and other supporting information. Geneva, World Health Organization.

[26]. WHO. (2003). Malathion in drinking water. Background Document for Preparation of WHO guidelines for drinking water quality. Geneva: World Health organization (WHO/SDE/WSH/03.04/103)

[27]. Yadav, S.S.., and Kumar, R. (2011). Monitoring Water quality of Kosi River in Rampur District, Uttar Pradesh, India. Advances in Applied Science Research. 2 (2):197-201.

Saranya.M. "Assessment of Seasonal Changes in the Water chemistry of Valapattanam and Munderikadavu River in Kerala, Tamilnadu, India." IOSR Journal of Environmental Science, Toxicology and Food Technology (IOSR-JESTFT) 11.7 (2017): 77-82. 